\title{
The Geographical Expansion of the Indian Cultural Sphere Symbolized by the Metaphor of the Five Rivers of India and the Metaphor of the Four Rivers of Asia
}

\section{Shoson Miyamoto}

This article was read at the XXVII International Congress of Orientalists : at the 3rd Sectional Meeting, "South Asia in Ancient and Classical Times", under the chairmanship of Professor J. A. B. van Buitenan, University of Chicago: held at the University of Michigan, Ann Arbor, August 13-19, 1967. It was originally written for the Journal : Vol. XV, No. 2, March, 1967.

Chapter I......The "Five Rivers" and the Three Phases of of Aryan Colonization: (1) Aryan Nationalism; (2) Middle-Way Co-existence; (3) The International Dharma Kingdom of Aśoka.

The Aryan Middle Kingdom (Madhyadeśa) as founded at Kuru-Pañchāla,

(1) According to the Laws of Manu (Mānavadharma śāstra II, 21-22), the Middle Kingdom is considered to be the territory bounded by the Himavat (Himãlaya) in the north, the Vindhya Mountains on the south, Vinasana on the west and Prayāga (Allāhābād) on the east. According to the Śatapathabrämana $(1,4,14-16)$ the god of the sacred fire, Agni-vaśvānara, started out towards the east from the Middle Kingdom but did not cross the Sadānira river. Later, this land was gradually opened, Aryanized and called Videha. Videha was a noted Aryan frontier and as such was the site of debate conteste held at the palace of King Janaka of Videha. This fact was reported in the Brhadaranyakopanișad, a work bearing a philosophical orientation similar to the Buddhist standpoint of "of things as they are" (yathabhütañanadassana). Buddhism, in its concept of Majjhima janapada, inherited the 


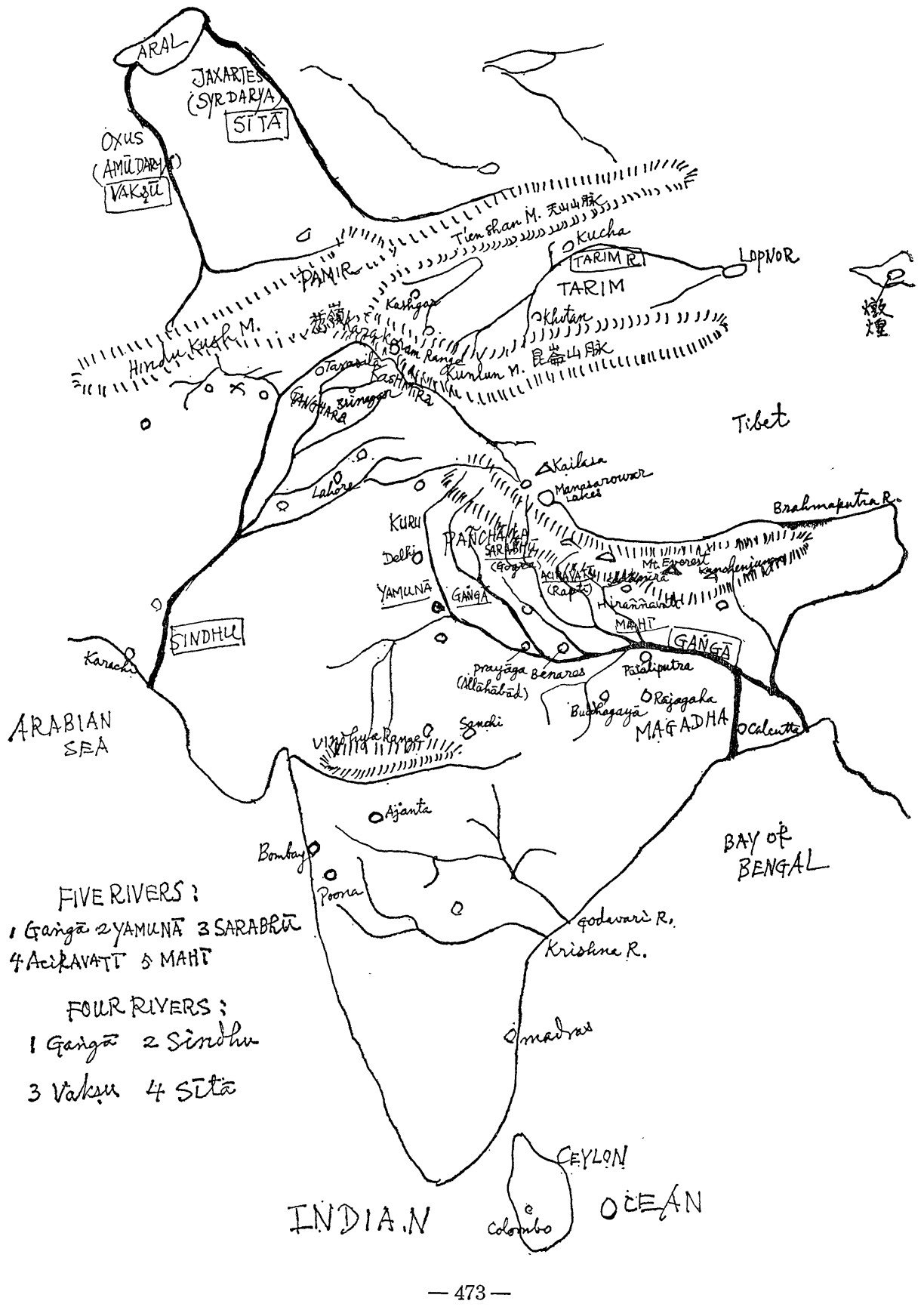


The Geographical Expansion of the Indian Cultural (S. Miyamoto)

can be viewed from two aspects; the Kuru-Jumna and Pañchāla-Ganges; first, to visualize in the Jumna culture of the Kurus, the archetype of the Aryan fatherland; and secondly, to discover in the Ganges culture of Pañchālas, the inception of Aryan Universalism. To extend this analogy further, we can say that Kuru-Jumna represents the warm and congenial community of the Aryan homeland while Jumna, in particular, symbolizes the Aryan motherland. In fact, the building of the present capital of the Republic of India, New Delhi, in the vicinity of Indraprastha, former capital of the Kuru country located along the upper reaches of the Jumna, may well have been a result of the yearning for the antiquity of the Aryan homeland. The city of Mathurā (Madhurā), the birthplace of Kṛ̣na, symbol of heroism, as well as the home of Thera Upagupta, the religious teacher of King Aśoka, together with the city of Agra (Ägra, Ägravana), the site of the Tãj Mahal, form a strategic center facing the Jumna River. Viewing. these three cities today, we can comprehend how the cultural life of the Aryan Middle Kingdom, occupying the territory of Kuru and Pañchāla, has: been enlarged and nourished by the twin rivers of the Jumna and Ganges.

In contrast to the Aryan stronghold of Kuru-Jumna, the Pañchāla. Ganges zone ranges through the belt of Sākiya, Kosala, Malla and Videha, contributing to the formation of the concept of an "Indistic Mother Nature." This area further broadens out into the large valley of Central India, watered by the rivers of the Ganges which flow from the base of the

Aryan notion of Madhyadesa. The boundaries of the Buddhist Middle Kingdom were: on the east, the town of Kajangala and beyond that the forest Mahāsāla; on the southeast, the river Salāvatī; on the south, the village of Setakaṇinika; on the west, the Brahmanic villages of Thūna; and on the north, Usĩraddhaja mountain. (Vinaya, Mahāvagga V, Cammakkhandhaka 13, 12, Vol. I p. 197). During the period of the Aryan Middle Kingdom (中國), although there existed designations for life in the fertile agricultural zone which was the central life sphere of the nation (民族の生活圈とし ての中國), the concept and principle of a Middle Way (中道) had not yet been born. For this concept to be created, first it was necessary that there be a period of arduous effort and difficulties in order to foster the free individual speculation that could lead ultimately to individual Enlightenment.......Satori. 
(4) The Geographical Expansion of the Indian Cultural (S. Miyamoto)

Himālayan mountain range.

The culture of the Upanișads, which follows this period, basically assumes the inherent concepts of the new third stage of Buddhist culture. (The first stage being the Punjab invasion and the second stage, the KuruPañchāla "Middle Kingdom"). This third stage was based upon the belief in the purity and equality of the four castes (catuvaṇimim suddhim, cattāro vaṇno samasamā). It was only after the Aryans had nestled in the bosom of the "Indistic Mother Nature", that they could originate the concept of Aryan Universalism to replace the confrontation of whites and blacks with a mutual and beneficial form of co-existence. In this respect, the PañchālaGanges culture was more closely associated with the trend towards universalism than that of the Kuru-Jumna which was preoccupied with the desire to create a "stable Middle Kingdom" (Dhurva Madhyamā dís ) as the "Sacred Land of the Āryans" (Ārya-varta).

Geographically, the Jumna (Yamunā) flows as the first river and the Ganges (Gangā) as the second, both watering the lands of the Aryan Middle Kingdom and joining together at Prayāga. From that point on, however, they flow under the name of the Ganges and gradually gather in the waters of the Gunti (Gomatī), the Gogra, i. e. the two rivers of the Gogra (Sarabhū, Saray $\bar{u}$ ) and the Rapti (Aciravatī), which form its upper reaches, the Gandak (Sadānīra, Hiraññavati, Mahī) the Sone (Sonā) and so on.

The "Five Rivers" (pañca-nadī : the Gañgā, Yamunā, Aciravatī, Sarabhū and Mahī) collect all the underground streams of the Himālayan range and join them together to form the Great Ganges. It seems as though these rivers might have forseen that King Aśoka, who ascended to the throne 218 years after the demise of the Lord Buddha, would create along the banks of the Great Ganges, Pātaliputra, as capital of the world's largest 'international' nation since the beginning of history.

There was nothing more wondrous than this important area of the

(2) S. K. Chatterji and V. Raghavan, "Language and Literature" in Age of the Nandas and Mauryas edited by K. A. Nilakanta Sastri. (Banaras: Motilal Banarsidass, 1952) p. 9. 
Great Ganges which faced the Himallayas and combined the "Five Rivers" to become the cultural and geographical origin of the world's largest capital of the "Kingdom of the Dharma." Still, it is even more extraordinary to realize that the Buddha left his homeland, enveloped in the mysterious atmosphere of the pure Himālayas and purposefully went southward for 800 kilometers to cross the Great Ganges, passing beyond the geographical site of Pățaliputra to further progress southward to the vicinity of Gayā. There he sought a place to carry out the religious practice of satori. Originally, the Buddha had been born and raised in an Aryan environment and while young had received an Aryan education. Why then did he have to seek his own religious practice, even selecting a non-Aryan background for the place of his new Enlightenment?

For his final place of training, Śākyamuni sat under the Bodhi tree at Gayā, an area far to the south below the capital Rãjagaha of Magadha, and there at that site, the wisdom and vision of the "Dharma which never before bad been heard" (pubbe ananusuttesu Dhammesu) arose within him. For the first time he attaind Correct Enlightenment (pathama-abhisambuddha-Vinaya, Mahāvagga I, 1) and he became the Buddha. His Enlightenment itself consisted of the illumination of the Middle Way.

The Great Ganges symbolizes the fact that the four castes are equal, that all men can become Buddha and that the self and others are identical (parātma-samatā). All of these concepts are included in the theory of the Middle Way of Co-existence, the futuristic and progressive theory unswayed by questions of race, class or ideology. A theory that united the self with others and worked towards mutual assistance with the various cooperating groups being led to the enjoyment of peace and prosperity.

Chapter II......The Growing Univeralism of Humanistic Racial Equality as Seen in the Metaphors of "Five Rivers" and "Four Rivers".

(3) Shoson Miyamoto, "The Historico-social Bearings of the Middle Way" in Journal of Indian and Buddhist Studies Vol. XIV, no. 2, (Tokyo: March, 1966) p. 15. 
In the first chapter of the Jñanaprasthana, we find the following statements: "As in the Jambudvīpa, the 'Five Rivers': the Gañgā, Yamunā, Sarayū, Aciravatī and Mahī are constantly flowing to the East, heading towards the Great Ocean, inclining to it and returning to enter it,...... so too, the Lokāgra-dharma is always heading towards the Arya-satya-abhisamaya......". The Mahävibhāșā, in commenting upon this passage adds : "The Venerable Kātyāyanī-putra was living in the East when he wrote Jñanaprasthana text and he set forth metaphor of 'Five Rivers' because of the existence of such rivers in the eastern region. In truth, however, in this world of Jambudvīpa there are 'Four Rivers': the Gañgā, Sindhū, Vakṣu and Sītā, all of which originate in Lake Anavatapta. The Gañgā river flows from the golden east side through the Elephant mouth and after once circling to the right around the lake empties into the East Ocean. The Sindhū river flows from the silver south side through the Ox mouth and after once circling to the right around the lake, flows into the South Ocean. The Vakṣu river flows from the lapis-lazuli west side through the Horse mouth and after once circling to the right around the lake, flows into the West Ocean. Finally, the Sīta river flows the crystal north side through the Lion mouth and after once circling to the right around the lake, flows into the North Ocean."

It appears that the metaphor of "Five Rivers" originated in the land of Early Buddhism and was subsequently handed down to the Aśoka Kingdom. It is said that in the Buddha's later years, Pātaliputra was being build by

(4) Jñanaprasthāna (發智論) Taisho XXVI, p. 918 c.

(5) Abhidharma-Mahāvibhāșā, Taisho XXVII, p. 21 c, 22 a.

(6) Mahāparinibbāna-suttanta D. N. XVI, 1, 24, Vol. II, pp. 87-89; Vinaya, Mahãvagga bhessajja-kkhandhaka 6, Vol. III, p. 228-230.

(7) Mahāprajñāpāramitā-śāstra (大智度論) Vol. III states "After the Buddha entered Nirvāṇa, King Ajātaśatru, abandoned Rājagṛha since the population was gradually diminishing and built a small town nearby. One yojana in length and breadth, its name was Pāțaliputra. It seems moreover, that it became the largest of all the towns." Taisho XXV, p. 78 a Étienne Lamotte, Le Traité de la Grande Vertu de Sagesse, Tome I, p. 186-187.

(8) Nundo Lal Dey, The Geographical Dictionary of Ancient and Mediaeval India (London: Luzac \& Co. 1927) pp. 151-154. 
Sunīdha and Vassakāra, ministers of Ajātaśatru, the King of Magadha. From a mere ferry place along the Ganges, this city became the capital of the Aśoka Kingdom developing into a world center for politics, economics and culture. Furthermore, it added something of a more cosmopolitan nature to the Buddhism of Aśoka. It was Aśoka, who pioneered the way to the Buddhism of Kaniṣka, the latter making his capital in Puruṣapura(Peshāwār) of Gandhāra, an area famous since ancient times for international cultural exchange. Kanișka's ideal was the promotion of a humanistic racial equality throughout Central and Northern India and also encompassing Central Asia.

The image of the period during which the Aryan pioneering advanced to the east along the drainage basin of the Great Ganges can be symbolized by the region enompassed by the Himālayas and Ganges river. It was a great wonder (unprecedented, abbhuta) to the Aryans, who had never previously known the Ocean, that the Ganges flowed into and fused with the Great Indian Ocean becoming one flavour (ekarsa) and bearing the same satly taste (lonarasa). Since even Śākyamuni coming as far distant as Magadha from his native country in the Himālayan ranges, was captivated by the fascination of the Ganges, it stands to reason that there is some connection between this feeling and the desire that all men might become Buddha. Equality for the four castes and a religious community (sangha) with one flavour and the same salty taste became the new slogan for this peiod. Of the five rivers, it is said that the Ganges flowing to the east, in particular bears great happiness and prosperity and the pratice of washing away $\sin$ and vice by performing ablutions in its waters has been perpetuated from ancient times up to the modern day. It is thus easy to understand how the metaphor of the "Five Rivers" is symbolic of Indian Buddhist culture and implies its lofty religious ideals.

(9) The eight unprecedented Dharmas (atthha acchariyā abbhutā dhammā) A. N., Atțhaka-nipāta 2, Mahāvagga, 19 pahārāda, Vol. IV, pp. 198-199, 202; 20 Uposatha, pp. 206-207; Udāna, 5 Soṇatherassavagga, pp. 53, 55.

(10) Just as the Ganges is always flowing to the East, heading towards the Great Ocean, there tending towards it, inclining to it and returning to enter 
The metaphor of the "Four Rivers" on the other hand, clearly symbolizes the sphere of Kaniṣka's Buddhism. If we examine this from the modern viewpoint, we can obviously perceive how the conception of world geography had expanded in union with broadening of Buddhist culture. The latter had now become Asianized, transcending the borders of India. This can best be expressed by the concept: "All sentient beings without exception have a Buddha nature," which is found in the Mahäparinirvanna Sütra. Here the Indian centered Jambudvipa world is transcended and the desire was born for the remainder of the world to become Buddhist. In precise, this encompassed the Greek colony (yona-loka) and the regions of the Oxus, Jaxartes and Yarkand rivers. We can thus see the arrival of a new age in the subsequent liason between Greek art and Buddhist ideals, or in other words, the beginning of the Graeco-Gandhara Buddhist art that was to serve as a vehicle of Buddhist expansion throughout the Asian countries.

The ninth sūtra in the chapter on Sorrow and Pleasure (Sukha-duhkham) of the Ekottara Āgama states the following: "When the 'Four Rivers' (Gangā, Sindhū, Vakṣu, Sītā) enter the Great Ocean, they lose their original names and only the name of the Ocean is mentioned. This is also similar to the four castes. What are the four? They are the Kșatriya, Brāhmana, Vaiśya and the Súdra. In the abode of the Tathāgata, they all shave their beards and the hair on their heads. Wearing the three robes of the Dharmas, they leave their homes to become recluses and to study the way. They do not return to their original caste name again and they are said to be priests and sons of Sakyamuni. Why is this? The reason is because people in the religious community of the Tathāgata are like this Great Ocean and the Four Noble Truths are like the Four Great Rivers entering into the city of safety, Nirvāṇa."

it, so too the Eightfold Noble Path and the Four Noble Truths always tend towards Nirvāṇa, incline towards it and return to enter it. (nibbāna-poṇa, nibbāna-ninna, nibbāna-pabbhāra).

(11) S. N. XLV Magga-saṃyutta, 4 Gaṇga-peyyala, 91-96. Pācina, 97-102. Samuddha, Vol. V, pp. 38-40.

(12) Taisho II, p. 658 c. 
It is chiefly in the Scriptures of the Sarvāsitvādins, the most influential school in Northern India at the time of Kaniṣka reign, that we can find the metaphor of "Four Rivers". On the contrary, the Theravāda Scriptures of Ceylonese Buddhism which was inroduced by Mahinda, son of Aśoka and thereby was the old traditional Buddhism of the Aśoka Kingdom, speak of the metaphor of "Five Rivers" of Great Ganges. But therein no trace of "Four Rivers" can be found. For example, the Pāli nikāyas in discussing the cosmology of the "Seven Suns Rising", only talk of "Five Rivers" and "Seven Lakes" (Anotatta....... and Mandakini). But the Agamas and Abhidharmas which were introduced to China from Northern India and Central Asia mention "Four Rivers" and "Anavatapta Lake" as the fountain head, referring to the same cosmology of "Seven Suns Rising", instead of "Five Rivers". I am mentioning this as an example of the changing features of the Sacred Scriptures. I think that it is because of that the Agamas are to be in "History and Society" in order to serve for the welfare of the world as said in the Buddha's missionary proclamation.

In the life of Tao-An (312-385), the influential priest-scholar, who was known for his declaration on the equality of the Buddhist fraternity, we can find an episode related to the former metaphor of the "Four Rivers". In the chapter, "Interpreters and Commentators" of the Kao seng chuan (高僧傳, chap. 5 part ${ }^{(13)}$ ) it states: At the time of the Wei and Tsin dynasties, a priest was generally named by his teacher and the surnames varied. But Tao-An believed that the Great Master was the origin and the base and that no teacher was more worthy of respect than Sankyamuni. That is why he has everyone receive the name of Śākyamuni. Later, when they obtained the Ekottara-Āgama, there it stated that the Four Rivers enter the Ocean and no longer retain the original name of the river. Thus when the four castes become priests, all shold be called sons of Sākyamuni. As this idea was proven to agree with the sutras, since then it has become a permanent practice."

(13) Taisho L, p. 352 c-353 a. 
Chapter III......The Central Asian Meeting of Western and Indian Cultural Influence and the Chinese Cultural Expansion of the T'ang Dynasty.

Since the world view of the "Four Rivers" is based upon the concept of Central Asia at the time of the colonial expansion of western culture, the identification of the Vakșu with the Oxus or Amū-Darya river and the Sìtā with the Jaxartes or Syr Darya must have been the original view. Therefore, in Hsüan Tsang's Record of Travelling in Buddhist Countries (Ta T'ang Hsi-yü-chi), the identification of the Sìtā with the Yarkand river, which flows through the Tarim Basin to Lake Lopnor, must be a later and secondary view based upon the influence of the Imperial expansion of the T'ang dynasty.

We have considerable historical materials in which the metaphor of the "Four Rivers" is recorded. Among them are some special documents

(14) Nando Lal Day, The Geographical Dictionary of Ancient and Mediaeval India p. 187; and Mochizuki, Great Buddhist Dictionary (Tokyo: Shinkyō Mochizuki, 1931) p. 1878 a, mention two traditions: one which identfies the Jaxartes with Sìtā and the other which identifies the Yarkand or Tarim River with Sìtā. Day seemed to prefer the first tradition but Mochizuki states that there is no reliable proof by which to decide whether the Sìtā should be identified with either the Jaxartes (Syr Darya) or Yarkand Rivers which empties into Lake Lapnor.

(15) In the cosmological story of the world of Jambudvipa, it is said that Four Rivers are flowing out from the four sides of Anavatapta or Anotatta in the following order:

1. Ganges......eastward

2. Sindhu.......souhward

3. Vakṣu.......westward

4. Sìtā.......northward

Dīrgha-āgama 30, 世記經, Taisho I, p. 116 c; 大樓炭經 I, Taisho I, 279 a ; 世 起經 Taisho I, p. $313 \mathrm{a}$; 起世因本經 Taisho I, p. $368 \mathrm{a}$; 大毘婆沙論 CXXXIII, Taisho XXVII, p. 691 a; 大智度論 VII, Taisho XXV, p. 114 a; Étienne Lamotte, Le Traité de la Crande Vertu de Sagesse (Louvain; Bureaux de Muséon, 
which list the Sìtā as the third river in the order of : the Gangā, Sindhū, Sìtā, and Vakṣu, instead of the usual listing of the Sìtā as the fourth river. This is apparently a later invention reflecting the Chinese viewpoint.

1944) p. 450; Ta T'ang Hsu-yü-chi 大唐西域記 I, Taisho LI, p. 869 b; Thomas Watters, On Yuan Chwang's Travel in India (London: Royal Asiatic Society, 1904) pp. 32-35.

(16) Ekottara-āgama 40, 1 Taisho I, p. 812 a; Sappata-soryiyunaya-kyō ( $A J a$ panese Alphabetical Index of Nanjiō's Catalogue of the Buddhist Tripitaka with Supplements and Corrections assumes its title to be the Sapta-süryodaya sūtra or Sütra of Seven-Sun-Risings. The Abhidharmakośa vyākhyā translated by Hüang-tsang, Vol. IX, Chap. 3, Taisho XXIX p. 58 a and Abhidharmakosabhașy translated by Paramārtha, Vol. V1lI, Taisho XXIX, p, 215 b. The late Dr. Louis de la Vallée Poussin listed Sītā as the third river in his work Vasubandhu et Yaçomitra, troisieme chaptre de L'Abhidharmakoça, cosmologie or Lokaprajñāpti (Bruxelles: Heyez, Imprimeur de L'Académie Royale, 1919) p. 77, but Dr. Poussin listed Sìtā as the fourth river in L'Abhidharmakośa de Vasubandhu traduit et annoté (Paris: Paul Geuthner, 1924) p. 147. The late Professor Chizen Akanuma presented a diagram of the Four Rivers in which he listed Sitã as the third river and giving ten sources for the listing in his work, A Dictionary of Proper Nouns in Indian Buddhism (Nagoya: Hajinkakushobō, 1931) p. 479. However in seven of the sources among the ten, the Sīta is not actually listed as the third river but rather as the fourth river, as demonstrated above in the fifteenth footnotes.

(17) As the Hsi-hü-chi (p. 34) mentions, there was a supposition that the Sīta had a subterranean course for a distance and where it emerged at the Chishih (積石) “Accumulated Rock" mountan, it became the source of the Yellow River (黃河). On behalf of the Chinese, there had long been a desire to have a source for the river in the Central Asian Mountain range. In his Phonetic and Linguistic Dictionary of the Tripitaka (一切經曋義), Hui-lin (慧 琳), who had being born in Kashgar or Shulik (疏勒) and who worked to enlarge and correct the work of Hsüan-ying (玄應), in referring to the Four Rivers, described the Sītā initially as follows, "The Sītā flows eastward, the Ganges southward, the Sindhu westward, and the Vakșu northward. And our Yellow River, being a tributary of the Sīta flows eastward." Taisho LIV, p. 313 b.

In 399 A. D., Fa Hsien (法顯) started from Chang An for the travels in Buddhist India, and in 402 arrived at Ta-li-lo (Dārel) Valley in the north Kashnmīr. Dārel situated on the western bank of the Indus and had been the ancient capital of Udyāna. He mentoned a celebrated wooden statue of the 
future Buddha, Maitreya Bodhisattva (Mile P'usa, Miroku Bosatsu in Japanese).

Chinese Priests asked Fa Hsien if he knew when Buddhist Dharma first went eastwards (佛法東過). Fa Hsien replied, “When I asked the people of those parts, they all said that according to an old tradition (古老相傳), Śramana (沙門) from India began to bring the Aphorisms (Sūtras) and Disciplines (Vinayas) across this river from the date of putting up the images of Maitreya Bodhisattva". "This image was put up about three bundred years after the Nirvanna of Buddha, which corresponds with the reign of P'ing-wang of the Chou dynasty (周氏平王), and from this date it was said that the Great Teaching began to be spread abroad at the setting up of the image (大呚宣流, 始自此像). That but for the transmission of Sākya's doctrines. by the mighty Maitreya, none could have caused the three Precious Ones. (三寶) to be preached abroad and foreigners to become acquainted with the faith. That the revelation of these mysteries was clearly not the work of man, and that thus the dream of Ming-ti of the Han dynasty (漢明帝) was not without foundation". And Fa Hsien also states that "According to the Chiu-yi (九譯), neither Chang Ch'ien (張騫?......114 B. C.) nor Han Ying (甘英) of the Han dynasty reached this point". (Fa Hsien, Record of the Buddhist Kindoms, 佛國記: The Travels of Fa Hsien, 法顯傳, Translated by Herbert A. Giles, London, Trübner \& Co., Re-tr. 1923). His statement is quite natural because it was Fa Hsien that who traveled Buddhist countries for the first time, not only in Central Asia but also in India.

Hsüan Chuang (玄牀) recorded the hearsay as follows: "this statue of Maitreya was erected by Madhyāntika (Majjhantika who was sent by Asoka to spread the Buddhist teaching in the North India). Hsüan Chuang also recoded that "the spread of Buddhism eastward dates from the existence of this image (自有此像, 法流東派)" And further Hsüan Chuang in the XII volume of the Hsi-hü-chi (Watters, Vol. II, pp. 282-85) states that "in the Pamīr Valley was a large Dragon Lake.......This lake sent forth on the west a large stream which joined the Oxus (縳葱河) to the east of Dhammasthiti and flowed west; and so all streams on the right (west) side flow west. On the east the lake sent out a large stream which went north-east to the confines of Kashgar, where it joined the Sītā and flowed east; and so all streams on this side of the lake flow eastward".

This description of the Sītā River seems to coincide with the above mentioned Chinese supposition. On the other hand Hsüan Chuang transcripted Jaxartes (Syr Daryā, Sìtā) as She river (葉河) in the Che-shih (Tashkend) and in the Ustrushna (Ura-tube). The transcription of Jaxartes was used to be Yao-sha river (藥殺水) in those Chinese historical records (Sui-shu, T'ang-shu etc.). And the Oxus (Amū Darya) was generally transcripted as 嬀水, 烏涺水, 縳葱河. 
The Geographical Expansion of the Indian Cultural (S. Miyamoto)

In order to trace the Chinese developments further, we find in the introduction to the Hsi-y ü chi or Record of Western Lands (629-645), Hsüan-tsang states the following:

There are "Four Lords" (四主) when there is no cakravartin of universal sovereign in the world of Jambudvipa. In the south (India) is the Lord of Elephants (象主), who rules over the land of heat and moisture, a climate suited to the elephant. In the west is the Lord of Precious Things (寶主) who rules over the sea abounding with pearis. In the north, the Lord of Horses (馬声) rules over the territory which is extremely cold and suited to horses. In the east (that is, China), the Lord of Man (人圭) rules over the land of harmony and peace with an abundance of people. Thus, the land of the Elephant-Lord is filled with people who are energetic, devoted to study and addicted to magical arts and who wear garments which cross the body leaving the right shoulder bare; their hair is made into a top knot in the middle and hangs down on the sides; kin and tribes associate in towns and live in houses of several stories. The territory of the Lord of Precious Things is filled with people who are rude and covetous, who wear short coats fastened to the left, cut their hair short and have long mustaches. They live in towns with walls and are expert in money-making. The territory of the Horse-Lord is filled with inhabitants of a wild and fierce nature, who commit murder without remorse, live in felt tents and are migratory herdsmen. In the land of the Man-Lord, the people are intelligeht, humane and just. They wear crowns and gowns, folding the left side of the gown over the right. They have a social order for dress and carriage. Although they are attached to the soil. when it becomes necessary they will move.

After observing the foregoing descriptions, we can draw the conclusion that in reality, this Chinese world theory of "Four Lords" is nothing more

(18) Ta T'ang Hsu-yü-chi: Thomas Watters, On Yuan Chwang's Travel in India pp. 35-36. 
than a transposition of the Indian cosmological concept of the Four Lands of Mount Sumeru : Uttara-kuru, Pūrva-videha, Jambudvīpa, Apara-godānīya. In such a manner, we can clearly visualize the geographical expansion and humanistic influence of the Indian cultural sphere.

Commercially, Central Asia may be designated as the "Silk Road", for the Chinese sought to trade for horses, pearls, jewels and so on. From the standpoint of international culture and art however, the Chinese necessities. consisted of the Buddhist sutras, translators of Buddhist texts and GraecoGandhara art, especially the images of the Buddhas and Bodhisattvas. That is why Central Asia can symbolically be termed the "Sutra Road" and: "Buddha-Image Road". Features such as these demonstrate the trend of influence that was generally moving towards China from west to east. It was only from the time the Chinese succeeded in building the great T'ang: kingdom that they began to act imperialistically. They became offensive not only politically but culturally. For instance, I-ching (義淨) who was: so famous for his Record of Buddhist Religion as Practiced in India and the Malay Archipelago (A. D. 671-695) compiled the Record of Priests in Search of the Dharma (求法高僧傳, Gūhō-kōsō-den, ch'iu-fa kao-seng-chuan) describing the lives of sixty Chinese priests who travelled through Central Asia and India in search of Buddhist culture and thought during fifty' years of the T'ang Dynasty (ca. 635-691 A. D.). Further, it is worth noticing that both Hsüng-tsang's Travel-Record and this Priests-Record by I-ching have the title of “Great T'ang Western Countries” (Ta T'ang Hsi-yü, 大唐西域).

Finally, I must say that further research and elaboration can be done in relation to the topics I have discussed here by consulting other Chinese

(19) I-Tsing: A Record of the Buddhist Religion as practised in India and the Malay Archipelago (A. D. 671-695), Nan-hai-chi-kuei-nei-fa-chuan, Nankai-ki-ki-nai-hō-den. 南海寄歸內法傳, translated by Junjiro Takakusu (Oxford: The Clarendon Press, 1896). 
The Geographical Expansion of the Indian Cultural (S. Miyamoto)

works and also the Purāna sources of Indian epic literature as well as the scientific records of the modern expeditions.

Especially we need to consult with those scientific reports of the expeditions and explorations by Sven Anders Hedin (1865-1952) [Scientific Results of Journey in Central Asia, 1899-1902, 8 vols (1904-7), Transhimalaya, 3 vols (1909-12), Overland to India, 2 vols (1910), Southern Tibet, 12 vols (1917-22), Scientific Results of Sino-Swedish Expeditions, 1927-35, 30 vols (1937-42)], Sir Aurel Stein (1862-1943) [Serindia 5 vols (1921), Innermost Asia, 4 vols (1928), On Ancient Central Asian Tracks, 1933], Albert Grünwedel (1856-1935), Albert von Le Coq (1860-1930), Paul Pelliot (1878-1945) and others.

And further, thanks to the kind information of Dr. Shigeru Tayama, Specialist of the National Diet Library and the Vice-President of Association of the Innermost Asia, the following records of U. S. S. R. explorers should be added: Przheval'skii N.; Tret'e Puteshestvi v Tsentral'noi Azii. Iz Zaizana cherez Khami u Tibet i na verkhov'ya Zheltoi Reki. S. P. B. 1833 ; Chetvertoe Puteshetvie v Tsentral'noi Azii. Ot Kyakhtui na istoki Zheltoi Reki, issledobanie cevernoi okrainui Tibeta i put' cherez Lob-Nor no basseeinu Tarima. S. P. B. 1888. Kozlov P. K.; Po Mongol i Tibetu(1899-1901) S. P. B. 1919.; Mongoliya i Kham (Trudui ekspedichi, soverschennoi v 18991901 g. pod P. K. Kozlova) S. P. B. 1906-1908.

(20) According to the Das Purạna vom Weltgebäude (Bonn: Universität Bonn, 1954) by Dr. Willibald Kirfel, the author of the Die Kosmographie der Inder (Bonn und Leipzig: Kurt Schroeder, 1920); the order of "Four Rivers": Gañgā, Sindhu, Vakṣu and Sìtā is varied in the Purānas. For example, Gañgā Sîtā Vakṣu Sindhu (p. 130, verses 38, 39, the second group texts); Sindhu Sìtā Vakṣu (p. 11, verses 28, 29, 30 the first group texts); Sìtā Vakṣu (p. 65, verse 13, first group); Vakṣu Sītā (p. 128, verse 21, 2nd group). I thank Mr. Yoshihiro Matsunami, Assistant in the Faculty of Literature, University of Tokyo, whose speciality is in the study of Purāna literature, for this information. 